\title{
SURVEY OF SELECTED AGENCIES CONDUCTED TO DETERMINE THE EXTENT TO WHICH THE NATION'S COALS ARE ADEQUATELY CHARACTERIZED
}

Technical Report No. 5

By

Judith M. Hower

Alan Davis

C. Philip Dolsen

William Spackman

\section{October 1977}

Date Published

Work Performed Under Contract No. EX-76-C-01-2030

\section{Coal Research Section}

The Pennsylvania State University

University Park, Pennsylvania

\section{U. S. DEPARTMENT OF ENERGY}




\section{DISCLAIMER}

This report was prepared as an account of work sponsored by an agency of the United States Government. Neither the United States Government nor any agency Thereof, nor any of their employees, makes any warranty, express or implied, or assumes any legal liability or responsibility for the accuracy, completeness, or usefulness of any information, apparatus, product, or process disclosed, or represents that its use would not infringe privately owned rights. Reference herein to any specific commercial product, process, or service by trade name, trademark, manufacturer, or otherwise does not necessarily constitute or imply its endorsement, recommendation, or favoring by the United States Government or any agency thereof. The views and opinions of authors expressed herein do not necessarily state or reflect those of the United States Government or any agency thereof. 


\section{DISCLAIMER}

Portions of this document may be illegible in electronic image products. Images are produced from the best available original document. 


\section{NOTICE}

This report was prepared as an account of work sponsored by the United States Government. Neither the United States nor the United States Department of Energy, nor any of their employees, nor any of their contractors, subcontractors, or their employees, makes any warranty, express or implied, or assumes any legal liability or responsibility for the accuracy, completeness or usefulness of any information, apparatus, product or process disclosed, or represents that its use would not infringe privately owned rights.

This report has been reproduced directly from the best available copy.

Available from the National Technical Information Service, U. S. Department of Commerce, Springfield, Virginia 22161.

Price: Paper Copy $\$ 4.50$

Microfiche $\$ 3.00$ 


\section{SURVEY OB SELESTED AGENCIES CONDUSTED TO DETERMMONE}

\section{PUE EXTENT TO WUISH THE NATUONOS SOALS} ARE ADEQUATESY CHARASTEROZED

by

Judith M. Hower, Alan Davis, C. Philip Dolsen and William Spackman

PSU-TR-5

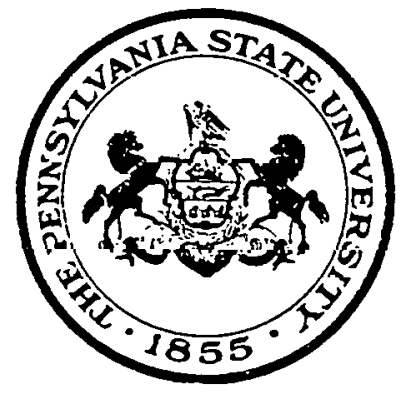

COAL RESEARCH SECTION

THE PENNSYLVANIA STATE UNIVERSITY 
THIS PAGE

WAS INTENTIONALLY

LEFT BLANK 


\section{ABSTRACT .}

A survey was conducted to determine the extent to which the Nation's coals were adequately characterized. Ouestionnaires were sent to 81 agencies in the coal community selected to form a representative cross section of the organizations concerned with coal characterization. Fifty-nine completed Questionnaires were received. Respondents included representatives of the agencies with the longest experience in characterization and those in the best position to know the status of our knowledge of the composition and properties of the coals comprising the Country's coal fields. Analysis of the responses to the Questionnaire resulted in the following conclusions:

1. the Nation's coals are inadequately characterized for their efficient and effective use, this being particularly true in relation to coal conversion technology and maintaining environmental quality;

2. the number of agencies conducting coal characterization programs is too small. to meet the Nation's needs within the time frame required;

3. the scope of coal characterization programs should be expanded to develop a broader spectrum of basic compositional and performance data. 


\section{TABLE OF CONTENTS}

\section{Page}

ABSTRACT . . . . . . . . . . . . . . . . . . . . . . iii

INTRODUCTION . . . . . . . . . . . . . . . . . . . . . . . . . 1

STUDY METHODS . . . . . . . . . . . . . . . . . . . . . . . 3

RESULTS OF THE STUDY . . . . . . . . . . . . . . . . . . . 4

THE SUPPLEMENT TO THE STUDY . . . . . . . . . . . . . . . . . 31

SUMMARY AND CONCLUSIONS . . . . . . . . . . . . . . . . . . 31

APPENDIX I - United States Coal Data Questionnaire . . . . . . . 35

APPENDIX II - Special Responses of the Pittsburgh Energy

Research Center to Questions 6 and 7 ...... 39

APPENDIX III - Notes Resulting from Personal Contacts at

Selected Agencies to Determine Feasibility of

Cooperative Efforts in Connection with the

PSU/ERDA Research Program . . . . . . . . . . 


\section{Introduction}

The development of information on the characteristics of coal and coal seams tends to progress as one approaches the actual utilization of the coal and the extent of characterization varies with the end use of the material. In the earliest stages of coal exploration, seam thickness and lateral extent may be the only characteristics recorded. As exploration proceeds and as the mining phase approaches, it is usual to mount a core drilling program involving closely spaced drili sites in order to define the mining condition's that will be encountered. Durtng this phase additional information on the composition and properties of the coal normally will be obtained. Among the first characteristics on which information is sought are the coal's ash yield, sulfur content and calorific value. Additional characteristics that often are examined at this time include the coal's moisture content, its volatile matter content and the quantity of fixed carbon that it contains. Additional basic information is found in the "ultimate analysis" which provides data on the concentrations of carbon, hydrogen, nitrogen, sulfur, and oxygen. The aggregate of the above would appear to comprise the "minimal coal data" required before utilization proceeds.

The information on coal characteristics which is required beyond the "minimal coal data" depends, lu a large degree, on the coal's end use and whether or not it will be cleaned and beneficiated in preparation for use. If the coal is scheduled for combustion in utility 
bo ilers, a grindability index, and ash fusion analysis and information on the elemented chemistry of the ash will be among the data required. If the coal is to be used in metallurgical coke production an additional array of characteristics will be explored. Included in the analytical procedures will be maceral analyses, vitrinite reflectance analyses, free swelling index tests and plastometer tests. Data also will be sought on the coal's coking characteristics, e.g. the pressure it will exert. nn oven walls, its expansion and contraction characleristics and the strength and reactivity of the coke that the coal will produce.

In producing coking coals it is desirable to optimize mining plans to insure production of coal of uniform (or at least acceptable) characteristics over the life of the mine. This requires the detailed characterization of each coal seam to be mined and the contouring of coal characteristics over the area to be mined. The preparation of the coal requires adequate coal washability data for preparation plant design and operation.

The motivation for adequately characterizing cool prior lu use in combustion and carbonization lies in the strong relationship between the coal quality control and the efficiency and effectiveness of the utilization process. Two things indicate that the scope and extent of coal characterization efforts will have to be expanded now, in preparation for the immediate future. One of these is the increasing concern for the quality of our environment and the need to know, for example, the extent to which particular coal reserves are radioactive or contain potentially toxic trace elements. The second is 
the eminence of coal gasification and coal liquefaction. In comparison to combustion and carbonization these are sophisticated technologies in which coal characteristics will influence product yield, product quality, by-product yield, reject yield, and operational efficiency.

In view of the above it is important to establish the extent to which the Nation's coal resources are adequately characterized for the today and tomorrow in the realm of coal utilization. The study described in this report has sought to make this determination.

\section{Study Methods}

The study reported herein consisted of four steps:

1) design and preparation of a suitable questionnaire;

2) selection of a representative list of agencies known to produce and/or use analytical data on coal;

3) transmittal of the questionnaire to the selected agencies and evaluation and summary of the completed and returned questionnaire;

4) analys is of summarized questionnaire data and development of conclusions.

As a supplement to the study, Penn State personnel personally contacted 19 agencies, largely to determine how cooperative efforts might best be developed, and this provided some additional information on the quality and type of data available.

The questionnaire used in the main study was designed so that answers could be supplied by simply checking the correct response 
or by recording an "off the cuff" numerical estimate or, at worst, by providing a one to three word answer. The objective was to obtain as much reliable information as possible with a minimum effort on the part of the responder.t. It was felt that to pursue a more complicated course of action would result in a very 1 imited response. The final version of the questionnaire as used in the survey is presented in Appendix 1.

Eightymone agencies were selected to receive the questionnaires. These included representative organizations in major sectors of the coal community. Table 1 lists the agencies selected and identifies them with the coal community sector to which they belong. As is evident from the Table, 25 State Geological Surveys received the questionnaires, 15 Federal agencies, 16 ERDA University contractors, 10 representatives of the coal industries, 4 oil industries, 4 independent research corporations, and 5 other agencies representing diverse industrial sectors.

\section{Results of the Study}

Fifty-nine of the 81 questionnaires sent to agencies in the coal community were completed and returned. Table 2 provides information on the percentage return from each of the agency classes. The overall return of the $73 \%$ of the questionnalres 15 above normal for this type. of survey. Also, the distribution of returns within classes appears to provide a properly balanced, well informed and experienced set of respondents which in turn gives credibility to any conclusion that may be drawn from the study. 


\section{Table 1}

Coal Community Agencies Receiving

Questionnaires

A. State Geological Surveys
7. Alabama
2. Alaska
3. Arjzona
4. Arkansas
5. Colorado
6. Illinois
7. Indiana
8. Iowa
9. Kansas
10. Kentucky
11. Maryland
12. Missourt

13. Montana

14. New Mexico

15. North Dakota

16. Ohio

17. Oklahoma

18. Pennsylvania

19. Tennessee

20. Texas

21. Utah

22. Virginia

23. Washington

24. West Virginia

25. Wyoming

B. Federal Agencies

1. U.S. Bureau of Mines

2. U.S. Geological Survey

3. Bartlesville Energy Research Center

4. Grand Forks Energy Research Center

5. Laramie Energy Research Center

6. Morgantown. Energy Research Center

7. Pittsburgh Energy Research Center

8. Argonne National Laboratory

9. Brookhaven National Laboratory

10. Lawrence Livermore Laboratory

11. Lawrence Berkeley Laboratory

12. Los Aldinus National Laboratory

13. Oak Ridge National Laboratory

14. Sandia National Laboratories

15. Pacific Northwest National Laboratory

C. ERDA University Contractors

1. Brigham Young University

2. Lehigh University

3. Montana State University 


\section{Table 1 (continued)}

4. State University of New York

5. Purdue University

6. University of Arizona

7. University of Illinois

8. University of Montana

9. University of North Dakota

10. University of Tennessee

11. University of Utah

12. Virginia Polytechnic Institute

13. West Virginia University

14. Western Michigan University

15. South Dakota School of Mines and Technology

16. University of Kentucky

D. Other Agencies

1. Coal Industry:

a. Amax Coal Company

b. Arch Minerals Corporation

c. Rituminous Coal R.eseárch, Inc.

d. Consolidation Coal Company

e. Eastern Associated Coal Corp.

f. Is land Creek Coal Company

g. Peabody Coal Company

h. Pittsburgh \& Midway Coal Mining Co.

i. The Pittston Company

$j$. Westmoreland Coal Company

2. Steel Industry:

a. Bethlehem Steel corporation

b. U.S. Steel Corporation

2. 0 iा Industry:

a. Exxon Research and Engineering Co.

b. GuTf Research and Development Corp.

c. Mobil Dil Research and Develupmenl Curp.

d. Shell Mining Ventures, Inc.

4. Research Corporations:

a. Batelle, Columbus

b. Hydrocarbon Research, Inc.

c. Institute of Gas Technology

d. Stanford Research institute

5. Other:

a. Dow Chemical Company

b. Fluor Engineers \& Constructors, Inc.

c. FMC Corporation

d. Johns Mansville Corporation

e. Rockivell International 
$\underline{\text { Table }} \underline{2}$

Percentage of Questionnaires Returned

in Each Agency Class

Agency

Class

1. State Geological Surveys

2. Federal Agencies

3. ERDA University Contractors

4. Other Agencies

a. Coal Industry

10

b. Steel Industry

c. $0 i 1$ Industry

d. Research Corporations

e. Other

5. Totals
Number of Questionnaires Sent

25

15

16

$11 *$

$69 \%$

$96 \%$

$87 \%$

13

\section{Percentage}

$40 \%$

$100 \%$

$25 \%$

$50 \%$

$40 \%$

$73 \%$

*Includes U.S.B.M., U.S.G.S. and 4 ERC Laboratories

The importance of "minimal coal analyses" (or "minimal coal data") was emphasized in the Introduction. The first question in the Questionnaire was: "Does your organization routinely (but not necessarily aiways) have performed the above "minimal coal analyses" on coals which are being tested or surveyed?" The responses to this question are summarized in 
Table 3 . Of the 59 responding agencies only 22 routinely conducted (or have conducted) these minimal analysis procedures. Thus, it would appear that in more than $60 \%$ of the cases, coals that are being evaluated in exploration, testing, and utilization programs are being subjected to less than these minimal analyses. State Geological Surveys and Federal Agencies employ minimal coal analyses to about the same extent, i.e. $42 \%$ and $46 \%$ respectively. ERDA University Contractors employ minimal analyses to characterize their coals in only $18 \%$ of the cases and the "Other Agencies" surveyed employ these procedures in $57 \%$ of the cases.

\section{Table $\underline{3}$}

Number of Agencies Performing "Minimal" Coal Analyses

\begin{tabular}{|c|c|}
\hline $\begin{array}{l}\text { Routinely } \\
\text { Performed }\end{array}$ & $\begin{array}{l}\text { Not Performed } \\
\text { Routinely }\end{array}$ \\
\hline
\end{tabular}

1. State Geological

Survey

2. Federal Agencies

3. ERDA University Contractors

4. Other Agencies

5. Totals
10

6 2

4

$.22 *$
12

5

8

7

32
2

2

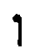

5

*Two additional agencies indicated that all minimal analyses except

forms of sulfur were performed and two additional agencies indicated that all minimal analyses except ultimate analyses were performed. 
In an effort to obtain an estimate of the extent to which minimal coal analyses were generated and available to characterize the remaining reserves, each respondent was asked to indicate the approximate number of analyses that the organization had on open file and readily available and which were pertinent to the remaining coal reserves. Ten of the 22 agencies which routinely generate minimal analyses stated that they had less than 100 on file (Table 4). Six organizations indicated that they had more than 1000. These six include 2 state Geological Surveys, the U.S. Geological Survey, the U.S. Bureau of Mines, 1 Energy Research Center and $10 i 1$ company. The U.S. Bureau of Mines stands alone in having 300,000 such analyses for no other agency responding has more than 3000 .

\section{$\underline{\text { Table }} 4$}

Number of Minimal Coal Analyses

On Open File and Pertinent to Remaining Coal Reserves

$<100 \quad 100-500 \quad 500-1000 \quad>7000$

Number of Agencies Performing Minimal Coal Analyses

*Two agencies indicated that all minimal analyses except forms of sulfur were performed and if this were not a limiting factor, they would have more than 1000 analyses on hand.

Several facts must be considered in assessing the significance of the abcve data. First, many of the analyses were made decades ago and 
pertain to worked-out seams or sections of seams. Second, a large amount of the older data was developed using analytical procedures which have since been abandoned and replsiced with more accurate methods. Third, in 1976 there were more than 6000 operating coal mines in the U.S. Finally, the Nation's coal reserves include a large and unknown number of coal seams, with no two seams possessing identical characteristics and with no seam remaining constant in its characteristics over its areal extent.

The data presented in Tables 3 and 4 , in themselves, lead to the suspicion that the Nation's remaining reserves are inadequately characterized. When considered in the light of the above facts, this suspicion is strengthened considerably.

The respondents to the questionnaire include agencies in a position to assess the degree to which the remaining coal reserves have been adequately characterized. Notable among these are the U.S. Bureau of Mines, the U.S. Geological Survey, and the 24 State Geolooical Surveys that have detailed knowledge of their particular areas. These agencies were asked to "Estimate the percentage of remaining coal reserves which have been or are being tested or surveyed by your organization for which you believe are adequate "minimal coal analyses" as defined above."

Table 5 presents the responses received from the above request. Two state Surveys indicated the percentage was unknown (i.e. ?) and three provided no response, perhaps indicating that they had no way of making the requested estimate. If these five Surveys are excluded from consideration and the other Survey estimates are averaged, the 
Table $\underline{5}$

\section{Estimating}

Agency

1. State Geological Surveys

Alabama

Alaska

Arizona

Arkansas

Colorado

Illinois

Indiana

Kansas

Kentucky

Maryland

Missouri

Montana

New Mexico

North Dakota

Ohio

Oklahoma

Pennsylvania

Texas

Utah

Washington

Wyoming

2. U.S. Bureau of Mines

3. U.S. Geological Survey
Estimates of the Perceritage of the Remaining Coal Reserves

Adequately Characterized by Minimal Coal Analyses

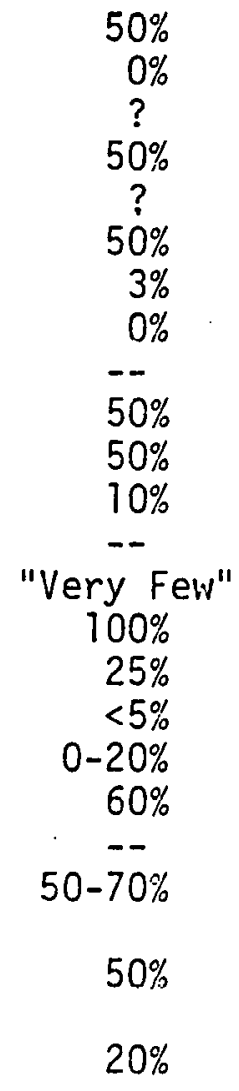


resulting estimate would be that $67 \%$ of the Nation's remaining coal reserves are not adequately characterized by minimal coal data. It is interesting if not meaningful, that the average federal estimate of adequately characterized reserves is $35 \%$, which translates into a $65 \%$ figure for the percentage of remaining reserves which are inadequately characterized.

In addition to the data produced through the performance of the minimal analyses procedures, it is Penn State's position that modern technology makes it essential to develop additional information on a coal's composition and properties before it is adequately characterized. This "Basic Compositional and Performance Data" is detailed in Table 6 . It should be noted that this list does not include some of the performance data deemed essential by the carbonization industry (e.g. oven wall pressure and expansion and contraction characteristics) and it does not include such data as surface area, porosity, and permeability which are important factors in both coal gasification and coal liquefaction.

The Questionnaire respondents were asked whether their organizations routinely performed (or had performed) each of the analyses listed as items 5 through 15 in Table 6 . The responses received are recorded in Table 7 . In this case the federal agencies are shown as four groups (items 2-5) in order that their similarities and differences might be observed. The Energy Research Centers, as a group, employ the greatest number of these basic analyses ( 8 of 11 ) but when considered individually the numbers range from 5-7 out of a possible 
Table 6

Basic Compositional and Performance Data

1. Proximate analysis

2. Ultimate analysis

3. Calorific value determination

4. Sulfur forms analysis

5. Maceral analysis

6. Vitrinite reflectance analysis

7. Ash-fusion analysis

8. Free-swelling Index

9. Gray-King coke type

10. Microhardness determination

11. Hardgrove grindability

12. Mineral species analys is

13. Major and minor element analysis

14. Trace element analysis

15. Washabllity andys is 


\section{Table 7}

Number of Agencies Routinely Performing Other Basic Analyses

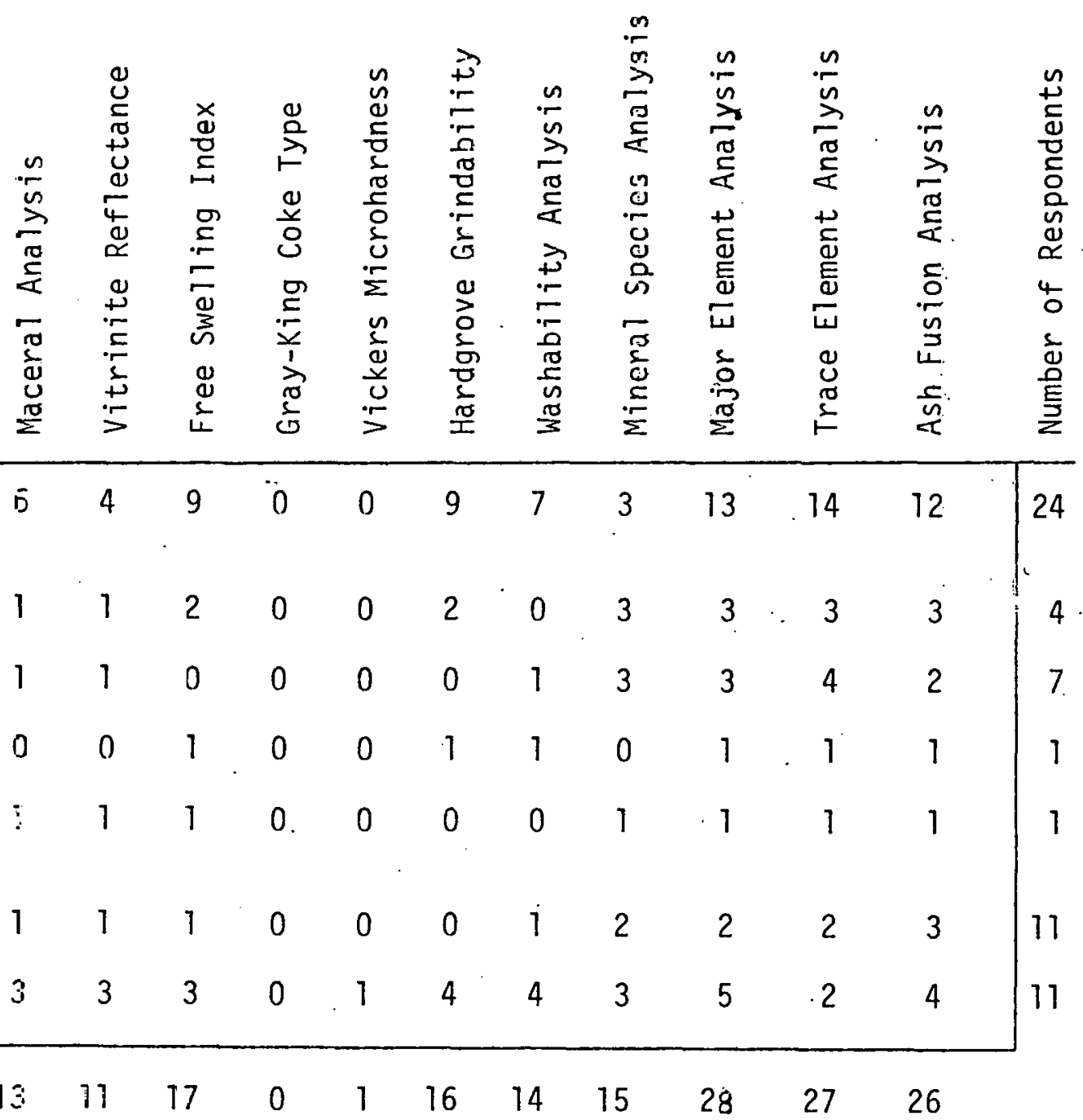


11. The National Laboratories, as a group, employ 7 of the 11 anaTytical procedures but individually the number ranges from $0-5$ out of 11 .

In contrast with the above the U.S. Geological Survey routinely empioys 7 of the 11 procedures and the U.S. Bureau of Mines 6 of the 11. State Geological Surveys as a group employ 9 of the 11 analytical procedures, but the individual variation is great ranging from 0-9. ERDA University Contractors vary from $0-6$ in the number of these analyses which they perform and Other Agencies vary from 0-9.

On aggregate the most frequently performed analyses are: 1) Major [loment Analysis (of ash), 2) Trace Element Analysis (nf ach) and 3) Ash Fusion Analysis. It was expected that Free Swelling Index Tests, Hardgrove Grindability Tests, and Vashability Tests would be more prominentiy represented than they are. Their failure to be represented by high numbers in the totals may reflect the fact that the Questionnaire respondents were largely data generators and analysis performers with only a minor representation of coal users. Although users needs are reflected in types of data that laboratories and research agencies produce, the perfection of the relationship is not great enough to eliminate all bias.

Table 8 summarizes the information on the extent to which these "Other Basic Analyses" are performed. Of interest in this Table is the fact that none of the 59 responding agencies perform the test which is required to establish the Gray-King Coke Type. This, or data from the Audibert-Arnu Dilatometer are required to classify a coal using the International System. In view of the volume of coal going to the export market it would appear desirable to include data 
$\underline{\text { Table }} \underline{8}$

Summary of Information

on Performance of

Other Basic Analyses

Number of

Agencies

Performing

Agencies with more than

1. Maceral Analyses

13

100 Analyscs

2. Vitrinite Reflectance

11

4

3. Free Swelling Index

17

4. Gray-King Coke Type

0

0

5. Microhardness

1

1

6. Hardgrove Grindability

16

5

7. Washability

14

3

8. Mineral Species

15

4

9. Majonr \& Mịnor Elements

28

11

10. Trace Elements

27

7

11. Ash Fusion

26

13 
from one of these two tests in any comprehensive characterization program. The Table also shows the number of agencies having more than 100 of each of these analyses on file. Depending on the analysis involved, the number of agencies performing the analysis varies from 1 to 13 . Less than $1 / 4$ of the 59 agencies have a significant number of ash fusion and major elements (in ash) analyses and less than $1 / 8$ have a significant quantity of data on trace elements and Free Swelling Indices. Less than $1 / 12$ of the 59 agencies have significant quantities of data on the characteristics established through the nther 7 analyses.

In connection with the use of coal characteristics data in achieving correlations between compositional characteristics and physical characteristics, it is important to have a variety of different -types of data developed on representative fractions of the same sample. This is also true if one is to use coal characteristics data in the development of predictive technology and it is true when one is concerned with describing the use potential of a given coal at a particular site. With these things in mind, the 59 respondents were asked to indicate the number of coal samples which their organization had fully characterized by performing all of the analyses listed in Table 6 . The responses to this request are recorded in Table 9. As is evident there are few instances in which this has been done.

From the results thus far described it is apparent that efforts at coal characterization have been, and are, comparatively limited in terms of the types of data that are routinely generated. A7though this was anticipated, the Questionnaire included two questions 


\section{Table $\underline{9}$}

Number of Organizations

- That Have Fully C.haracterized a Coal Sample by Performing all of the Analyses Listed in Tables

1 and 4 on Splits of the Same Sample

1. State Geological Surveys

2. ERDA Energy Research Centers

3. National Laboratories

4. U.S. Bureau of Mines

5. U.S. Geological Survey

6. ERDA University Contractors

7. Other Agencies 
aimed at determining the adequacy of the "Basic Compositional and Performance Data" for combustion, carbonization, and conversion technologies. The first of these two questions focused on analytical procedures judged essential for adequate coal characterization in conjuction with coal gasification and coal liquefaction. Table 10 summarizes the responses received to this question. The second question asked for a list of analytical procedures which the respondent's organization considered "essential for basic coal characterization for the purposes of relating to coal carbonization and combustion". Table 11 summarizes the responses to this request.

Examination of Tables 10 and 11 will show that a rather large number of recommendations was forthcoming in both instances. This would lead one to conclude that the Penn State coal characterization program should be expanded materially. It should be noted, however, that in the great majority of the cases the recommendations are those of only one or two organizations. Exceptions to this are the Fischer Assay recommended by four organizations in connection with gasification and liquefaction and Gieseler Plasticity measurements coupled with pilot scale coke tesst.s recommended by 3 and 5 organizations respectively in connection with coal carbonization. This iack of coincidence of recommendations is judged to mean that the "Basic Compositional and Performance Data" are generally adequate in scope but that consideration should be given to adding Gieseler Plasticity and a Fischer Assay type analys is to the list.

In spite of the lack of agreement on additional analyses that should be included in a characterization program, there are several 
Table 10

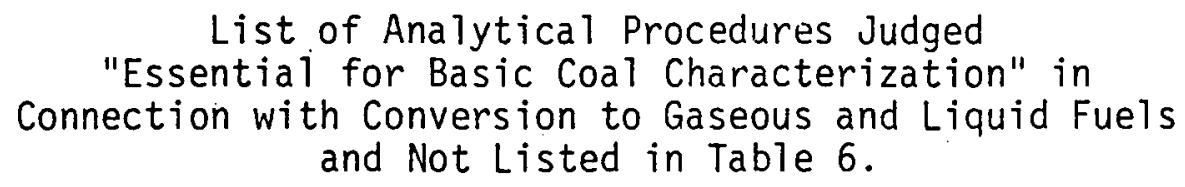

\section{Analytical Procedure}

1. Total and Water-Soluble Chlorine

2. Radioactive Determination

3. Specific Gravity

4. Fischer Assay

5. Elemental Analysis

6. Viscosity of Moliten Ash

7. Particle-Size Classification

8. Low-Temperature Ash Analysis

9. Porosity

10. Permeability

11. Fluidity

12. Internal Surface Area

13. Environmentally Important Trace Elements

14. Other*
Number of Agencies Indicating Procedure
2

1

1

4

1

1

1

2

2

2

1

2

1

1

\footnotetext{
* In response to the request for suggestions of analytical procedures "essential for basic coal characterization" and not listed in Tables 1 and 4 , the Pittsburgh Energy Research Center provided 1 ists of their analytical procedures. These are contained in Appendix II.
} 


\section{Table 11}

List of Analytical Procedures Judged

"Essential for Basic Coal Characterization" in Connection with Coal Carbonization and Combustion and Not Listed in Table 6.

\section{Analytical Procedure}

1. Gieseler Plasticity

2. Pilot Scale Tests

3. Heat of Carbonization

4. Viscosity of Molten Ash

5. Specific Gravity

6. Chlorine

7. Density

8. Coal Carbonization Assays

9. Low Temperature Ash Analysis

10. Expansion-Contraction Tests

11. Coking Pressure Tests

12. Coke Strength under Plant Conditions

13. Audibert-Armu Dilatometer Test

14. Permeability

15. Elemental Analys is of Ash in Coke

16. Other*
Number of Agencies Indicating Procedure 
types of data that clearly are of importance and should be included. in at least some characterization efforts. Notable among these are surface area measurements, permeability measurements, and measurements of porosity including total pore volume and pore size distribution. Such analyses are, in fact, a part of the PSU coal characterization program, but they are regarded as "Special Analytical Data" (Table 12) because the analyses are performed on a restricted number of samples.

Table 13 concerns another aspect of the questionaire survey. Included in the Questionnaire was the request for the respondent to "indicate whether it would be possible for your organization to supply The Pennsylvania State University with samples of coal from operating mines or coal prospects over the next four years". The intent was that these samples would be supplied to supplement PSU's sampling effort and would provide suitable samples for use in the PSU/ERDA research program. Table 13 summarizes the responses to this request. Examination of the Table will show that there are 30 sample sources available to PSU affording access to a variety of sample types. Of particular value is the fact that 16 State Geologicai Surveys and the U.S. Geological Survey have indicated a willingness to assist. This provides for a geographically broad coverage that will assist in screening areas and seams that are unstudied by PSU, enabling the proper scheduling of sites for PSU'S standardized sampling operation.

Still another aspect of the Survey is displayed in Table 14. Al though somewhat inappropriate the respondents were asked whether it would be useful from their organization's standpoint for PSU to 


\section{Table 12}

Description of "Special Analytical Data"

"Special Analytical Data: includes:

1. Surface area data

2. Horosity data

3. Adsorptive capacity data

4. Reactivity data

5. Permeability data

6. Pyrite size consist data

7. Equilibrium Moisture data

8. Pyrolysis data

9. Liquefaction data

10. Gasification data 
Table 13

W. Potential Sources of Coal Samples

I for the ERDA-Research Program at the Pennsylvania State University

Source Agency

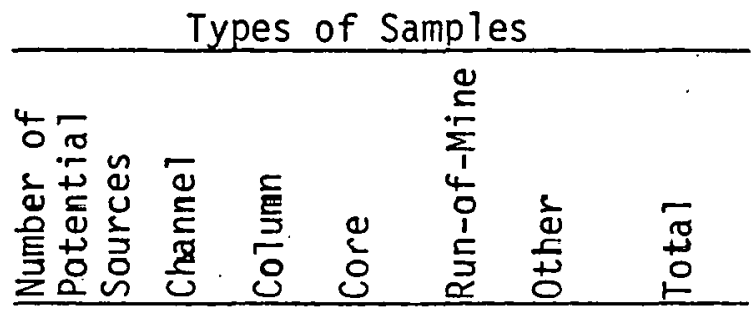

1. State Geological Surveys $\begin{array}{lllllll}16 * & 15 & 2 & 9 & 10 & 2 & 38\end{array}$

2. ERDA Energy Research Centers

3. National Laboratories

4. U.S. Bureau of Mines

$\begin{array}{lllllll}1 & 0 & 0 & 0 & 1 & 1 & 2\end{array}$

5. U.S.G.S.

$\begin{array}{lllll}2 & 0 & 0 & 0 & 2\end{array}$

6. ERDA University Contractors

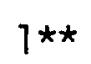

$7 * \star$

1

ther Agencies

lotal Samples

\begin{tabular}{rrrrrrr}
3 & 2 & 2 & 1 & 1 & & 6 \\
6 & 3 & 3 & 3 & 4 & 2 & 15 \\
\hline
\end{tabular}

\footnotetext{
* Some indicated that funding would be required to permit the supply of samples
**Samples would be supplied provided confidentiality is maintained in the case of the U.S.B.M.


Table 14

Agencies Indicating a Desire to Have PSU

Perform Certain Coal Analyses on Samples

Which the Agency Would Supply

Type of Analysis

Agency

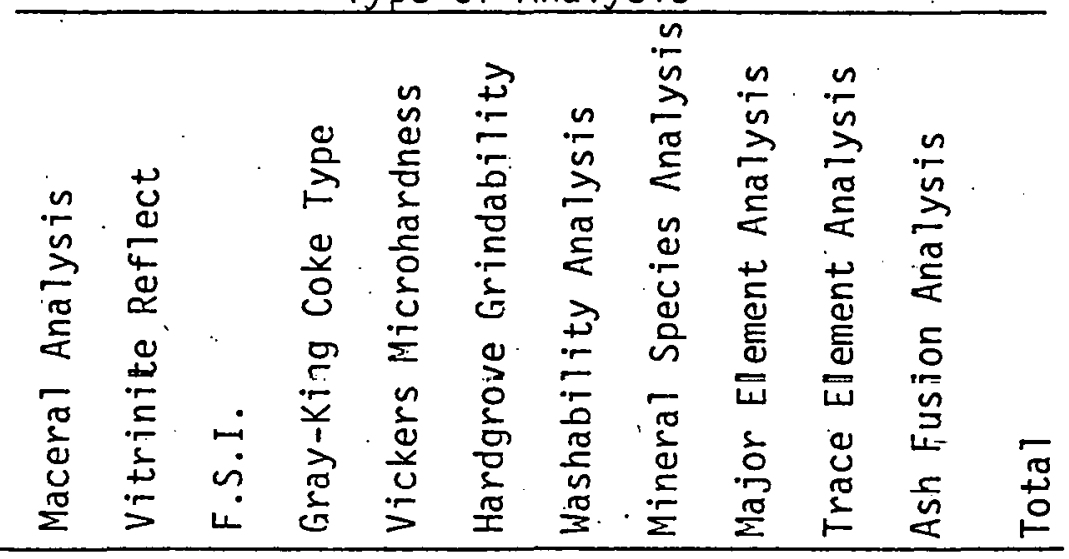

1. State Geological

Surveys

$\begin{array}{llllllllllll}13 & 8 & 8 & 8 & 7 & 11 & 11 & 10 & 10 & 11 & 12 & 109\end{array}$

2. ERDA Energy Re-

search Centers

3. National Laboratories $\begin{array}{lllllllllllll}3 & 3 & 2 & 2 & 2 & 2 & 2 & 3 & 3 & 3 & 2 & 27\end{array}$

4. U.S. Bureau of Mines

5. U.S. Geological Survey

$\begin{array}{lllllll}1 & 1 & 1 & 1 & 1 & 1 & 1\end{array}$

7

6. ERDA University

Contractors

7. Other Agencies

8. Totals

$\begin{array}{lllllllllllll}1 & 1 & 1 & 1 & 1 & 1 & 1 & 1 & 1 & 2 & 1 & 12\end{array}$

$\begin{array}{llllllllllll}2 & 2 & 2 & 1 & 1 & 2 & 1 & 3 & 3 & 4 & 1 & 22\end{array}$

$\begin{array}{llllllllllll}20 & 15 & 13 & 13 & 12 & 18 & 17 & 19 & 18 & 21 & 17 & 183\end{array}$ 
perform certain analyses on coal samples which would be supplied by their organization. The implication intended was that the data generated would be returned to the respondent's organization for its use. The question is somewhat out-of-place because the organizations being surveyed are data generators and analysis performers, hence, would have minimal needs for someone else to produce data for them. In spite of this, there was a significant number of agencies that felt they could benefit from this kind of cooperation and service. As may be seen from the Table, the State Geological Surveys expressed a considerable interest in this kind of an interchange as did the U.S. Geological Survey. At first glance, the small number of ERDA University Contractors expressing an interest in this sort of cooperation appears peculiar and is inconsistent with the numerous requests for data that are, in fact, received by PSU from ERDA contractors. The explanation for this lies in the manner in which the request was worded in the Questionnaire (see Appendix I). Question 8 asked whether the respondent's organization rould supply Penn State with samples from inines or prospects. Most ERDA University Contractors are not sampling oriented and only two agencies responded in the affirmative. Question 10 was phrased as follows: "If your response to Question 8 was $\underline{\text { YES }}$, please indicate whether it would be useful for The Pennsylvania State Inniversity to perform any of the following andyses ..." By relating Question 10 to Question 8 in this fashion, oniy three agencies were eligible to respond and two of these expressed a desire to receive PSU generated analytical data. 
Examination of Table 14 will show that the interest in the recsipt of PSU generated data is the highest for trace element analyses and maceral analyses and lowest for microhardness, Gray-King, and F.S.I. data. Ranked according to the level of interest expressed the analyses fall in the following order:

1. Trace Element Analysis

2. Maceral Analys is

3. Mineral Species Analysis

4. Hardgrove Grindability Analysis

5. Major Element Analysis (in ash)

6. Washability Analysis

7. Ash Fusion Analys is

8. Vitrinite Reflectance Analys is

9. Gray-King Coke Type Determination

10. Free Swelling Index Determination

11. Microhardness Determination

Considering the problems inherent in the inappropriateness of this question in the Questionnaire and the problem of the way it was related lo Question 8 , the lovel of interest in all of the above analyses is high. This suggests that the "Basic Compositional and Performance Analyses" as conceived in the PSU/ERDA program do, in fact, form the desired core of an adequate coal characterization sys tem.

The last request contained in the Questionnaire asked each respondent to "identify those geographic areas in which your organization is (or expects to be during the next four years) carrying out coal exploration and/or coal characterization programs. Table 15 


\section{Table 15}

List of Areas to be Subjected to

Coal Exploration and/or Coal Characterization During the Next Four Years*

State

1. Alabama

2. Alaska

3. Arizona

4. Arkansas

5. Colorado

6. I17inois

7. Indiana

8. Iowa

9. Kansas

10. Kentucky

11. Maryland

12. Missouri
Specific Geographic Area

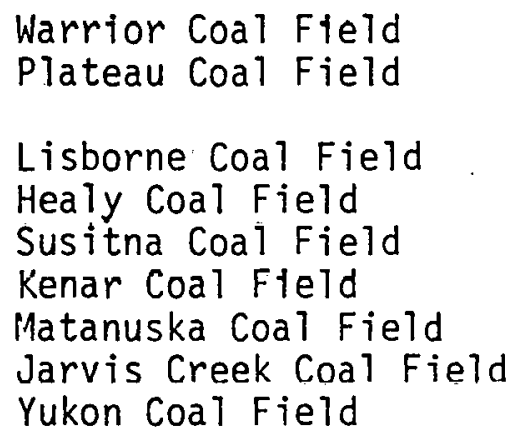

Deer Creek

Pinedale

Gulf Coastal Plain

Statewide

Statewide

Southwestern Indiana

Southeastern Iowa

Linn Counly

Bourbon County

Crawford County

Cherokee County

Neosho County

Montgomery County

Wilsons County

Osage County

Franklin County

Eastern Kentucky

Western Kentucky

Allegheny County

Garrett County

North-Central Missouri

Western Missouri 
Table 15. (continued)

13. Montana

14. New Mexico

15. North Dakota

16. Ohio

17. Oklahoma

18. Pennsylvania

19. South Dakota

20. Tennessee

21. Texas
Statewide

San Juan Basin

Raton Field

Datil Mountain Field

Several Smaller Fields

Williston Basin

Eastern Ohio

Statewide

Southwestern Pennsylvania Western Pennsylvania

Armstrong and Adjacent Counties

Western South Dakota

Eastern Tennessee

Wilcox Formation-South

Texas

Jackson FormationSoutheastern Texas

Claiborne FormationSouth Texas

Cretaceous Coals-South

Texas

Wasatch Plateau

Book Cliffs

Kaiparowits Plateau

Alton Field

Southwestern Virginia

Statewide

Kanawha County

Boone County

Webster County

Mercer County

Preston County

Northern Panhandle and entire area underlain

by the Pittsburgh Seam 


\section{Table 15 (continued)}

24. Wyoming

Hanna Coal Field

Hams Fork Region Green River Region

Pouder River Basin

Bighorn Basin

*The U.S. Bureau of Mines and the U.S. Geological Survey listed "all areas", "al1 regions" and "all basins." 
lists the responses on a state-by-state basis. As will become evident from a perusal of the Table, 23 states have. been identified as targets of coal exploration and/or coal characterization programs during the next four years and 68 specific areas are 1 isted.

The Supplement to the Study

As mentioned in the section on Study Methods, the main supplement to the study was provided by visitations of PSU personnel to 19 selected agencies. This was done largely to explore ways to develop cooperative efforts, but it also provided an additional opportunity to learn more about the quality and quantity of existing coal data and to discuss the ways in which the characterization program at Penn State might usefully be modified. Appendix III presents a summary of the results of these visitations. No recommended changes in the coal characterization program were forthcoming but specific interest was expressed by several agencies in contracting with Penn State to assist in coal sampling or coal analys is as a means of strengthening the organization's coal research effort.

\section{Summary and Conclusions}

A survey was conducted to determine the extent to which the Nation's coals were adequately characterized. Questionnaires were sent to 81 agencies in the coal community selected to form a representative cross section of the organizations concerned with coal characterization. Fifty-nine completed Questionnaires were received. Respondents included representation from the agencies with the longest 
experience in characterization and those in the best position to know the status of our knowledge of the composition and properties of the coals comprising the Country's coal fields. Analysis of the responses to the Questionnaire revealed the following facts:

1. In the opinion of the respondents, $50-80 \%$ of the Nation's remaining coal reserves are inadequately characterized.

2. Less than one-half of the agencies perform a "minimal coal analysis" on coal samples on a routine basis.

3. Only 12 agencies have more than 100 "minimal coal analyses" on open file.

4. None of the responding organizations routinely conduct the package of analyses designated "Basic Compositional and Performance Anaiyses".

5. Less than $1 / 4$ of the responding agencies have significant quantilies of ash fusion analysis and major element (in ash) anatysis.

6. Less than $1 / 8$ of the responding agencies have significant quantities of data on trace element contents and free swelling properties.

7. Less than $1 / 2$ of the responding agencies have significant quantities of data on the coal characteristics established through any of the following analyses:
a. Maceral analysis
b. Vitrinite reflectance analys is
c. Hardgrove grindability analys is
d. Washability analysis 

e. Microhardness analys is
f. Gray-King Coke Type analysis
g. Mineral species analysis

8. In total, five coal samples have been fully characterized by performing all of the analyses required to develop what was designated "Basic Compositional and Performance Data".

9. The responses to questions on the types of analyses necessary to relate coal characteristics to behavior in industrial processes led to the conclusion that the basic coal characterization performed by Penn State is generally adequate but that consideration should be given to adding the fipspler Plastonmeter Test and Fischer Assay.

10. Thirty agencies including sixteen state Geological Surveys and the U.S. Geological Survey were willing to act as potential sources of coal samples for characterization by Penn State. Sixty-eight specific areas were identified in which coal exploration will be carried out by the agencies during the contract period.

11. It appeared that Penn State could usefully cooperate with the coal research community by providing analytical data. The agencies which were interested in providing samples indicated in a significant number of cases that they would likc to have analyses performed for them.

From the above and from the contents of this report it is concluded that:

1. the Nation's coals are inadequately characterized for their efficient and effective use, this being particularly 
true in relation to coal conversion technology and maintaining environmental quality;

2. the number of agencies conducting coal characterization programs is too small to meet the Nation's needs within the time frame required;

3. the scope of coal characterization programs should be expanded to develop a broader spectrum of basic compositional and perfnrmance data. 
Appendix I

United States

Coal: Data Questionnaire 
UNITED STATES COAL DATA QUESTIONNAIRE

For the purposes of this survey we will regard a 'minimal coal analysis' as including all of the following analyses:

1. Ultimate analysis

2. Proximate analysis

3. Calorific value

4. Forms of sulfur

1. Does your organization routinely (but not necessarily always) have performed the above 'minimal coal analysis' on coals which are being tested or surveyed?

2. Approximately how many such minimal coal analyses does your organization have on open file and readily available which are pertinent to remaining coal reserves? For the purposes of this survey it is necessary only to consider coal reserves occurring in seams of greater than 30 inches and at depths of less than 3000 feet.

$$
\text { Number of minimal coal analyses on file }
$$

3. Estimate the percentage of remaining coal reserves which have been or are being tested or surveyed by your organization for which you believe there are adequate 'minimal coal analyses' as defined above. Again, it is only necessary to consider those reserves which occur in seams of greater than 30 inches and at depths of less than 3000 feet.

Estimate of adequate coverage of reserves with 'minimal coal analyses'

4. Which of the following analyses are routinely performed by or for your organization? Please indicate the approximate number of such analyses which you have on open file and readily available. If approximate numbers are known, complete Section $A$ only; if such numbers are not known, you should use Section B to provide an estimate within broad limits.

\begin{tabular}{|c|c|c|c|c|c|c|c|}
\hline \multirow[b]{3}{*}{ Maceral analysis } & SECTION A & \multicolumn{6}{|c|}{ SECTION B } \\
\hline & $\begin{array}{c}\text { No. on } \\
\text { file }\end{array}$ & None & $\begin{array}{r}0- \\
100\end{array}$ & $\begin{array}{l}100- \\
500\end{array}$ & $\begin{array}{l}500- \\
1000\end{array}$ & $\begin{array}{l}1000- \\
3000\end{array}$ & $>3000$ \\
\hline & & & & & & & \\
\hline $\begin{array}{l}\text { Vitrinite reflectance } \\
\text { analys is }\end{array}$ & & & & & & & \\
\hline Free-Swelling Index & & & & & & & \\
\hline Gray-King. Coke Type & & & & & & & \\
\hline Vickers Microhardness & & & & & & & \\
\hline Hardgrove grindability & & & & & & & \\
\hline Washability analysis & & & & & & & \\
\hline $\begin{array}{l}\text { Mineral species analys } \\
\text { (e.g.kaollinite, quartz, }\end{array}$ & & & & & & & \\
\hline Major element analysis & & & & & & & \\
\hline Trace element analysis & & & & & & & \\
\hline Ash fusion analysis & & & & & & & \\
\hline
\end{tabular}


5. Approximately how many coal samples has your organization characterized by having ALL of the analyses listed in Q. 4 performed on splits of the same sample?

6. Specify any analytical procedure, other than the 'minimal coal analys is' and those listed in Q. 4, which your organization considers to be essential for basic coal characterization for the purposes of relating to conversion of coal to liquid or gaseous fuels.

(attach list if necessary)

7. Specify any analytical procedure, other than the 'minimal coal analysis' and those listed in Q. 4, which your organization considers to be essential for basic coal characterization for the purposes of relating to coal carbonization and combustion.

(attach list if necessary)

8. Please indicate whether it would be feasible for your organization to supply The Pennsylvania State University with samples of coal from operating mines or coal prospects over the next four years.

9. If your response to Q. 8 was YES, please indicate whether the samples you could provide to Penn State would be

Channel samples

Column samples

Core samples

Run of Mine samples

Other (Specify)

10. If your response to $Q .8$ was YES, please indicate whether it would be useful for The Pennsylvania State University to perform any of the following analyses on the samples of coal which you would supply.

Maceral analysis

Vitrinite reflectance analysis

Free-Swelling Index

Gray-King Coke Type

Vickers Microhardness

Hardgrove grindability

Washability analysis

Mineral species analysis

Major element analysis

Trace element analys is

Coal ash fusibility

Ash fusion analysis 
11. Please identify those geographic areas in which your organization is (or expects to be during the next 4 years) carrying out coal exploration and/or characterization programs. 


\section{Appendix II}

Special Responses

of the

Pi.ttsburgh Energy Research Center

to

Questions $\underline{6}$ and $\underline{7}$ 
The Analytical Chemistry Branch provides to the engineering and research divisions of PERC routine physical and chemical analyses and special analytical services. Research is conducted for the development of new analytical chemical methods and improvement of established techniques for analysis of coals and related materials and products. The major techniques and their applications are listed below:

Gas Chromatography - Routine gas analysis of products of coal combustion and conversion processes. Controlled by a data processing system that collects, computes, and reports data from as many as 30 gas chromatographs.

Atomic Absorption Spectrochotometry and Specific Ion Electrode Analysis of metals in catalysts, seed materials in MHD, and trace elements in coals and conversion products.

X-Ray Diffraction and Fluorescence - Analysis of compounds and elements in catalyst materials, deposits, and effluents of coal combustion and conversion

Automated Surface Area-Pore Volume Analysis - Determination of internal structure and external surface in catalysts and fine particulate materials.

Micro $\mathrm{C}-\mathrm{H}-\mathrm{N}-\mathrm{O}-\mathrm{S}$ Analysis - Elemental analysis of minus $10 \mathrm{mg}$ samples of coal and coal products.

Rapid Sulfur Analysis - Determination of sulfur content of fuels in $50 \mathrm{mg}$ samples in 15 minutes.

ASTM Elemental Analysis - Measurement of $\mathrm{C}-\mathrm{H}-\mathrm{N}-\mathrm{O}-\mathrm{S}$ and ash contents by standard methods:

Solvent Analysis - Determination of benzene and hexane solubles and insolubles in coal liquids.

Viscosity Determination - Measurement of viscosity of coal liquids.

Water Analysis - Determination of biological and chemical oxygen de$\widehat{\text { mands }}(\overline{B O D}, \mathrm{COD})$ in waste waters. 
The Spectrometry Branch makes use of a variety of modern instrumental techniques to study the physical and chemical structure of coal and coal products and properties of air, water, and waste pollutants. These techniques and their major applications are shown in the following list:

High Resolution Mass Spectrometry - Characterization of liquid and solid products of coal conversion.

Low Resolution Mass Spectrometry - Analys is of gases from SYNTHANE and other processes.

Gas Chromatography-Mass Spectrometry - Analysis of light oil products and other liquid streams.

Spark Source Mass Spectrometry - Characterization of minor and trace elements in SYNTHOIL and SYNTHANE process streams.

Secondary Ion Mass Spectrometry - Depth profiles of elemental composition of conversion catalysts.

High Pressure Liquid Chromatography - Analysis of SYNTHOIL Iiquids.

Flame Photometric Chromatography - Sulfur analysis in SYNTHANE and SYNTHOIL gases.

Infrared Spectrometry - Determination of organic functional groups in coal liquids and composition of coal minerals. Studies of adsorbed species on catalysts.

Laser Raman Spectrometry - Investigation of deactivation of coal conversion catalysts.

U1traviolet Spectrometry - Analys is of aromatics in coals and products, phenols in waste waters, and organic groups and compounds.

Fluorescence Spectrometry - Detection of possible carcinogens in coal liquids.

Nuclear Magnetic Resonance - Determination of structure and element distributions in coal products.

Electron Spin Resonance - Determination of paramagnetic species (free radicals, charge carriers, transition $\mathrm{m}$ tal ions) in coal.s and products.

Low Temperature Ashing - Preparation of nearly undisturbed minerals from coals and products for more authentic analysis.

Scanning Electron Microscopy and X-Ray Analysis - Observation, photography, and micro-analys is of sma 11 areas on catalysts and of fly ash and coal minerals. 


\section{Appendix III \\ Notes}

\section{Resulting from Personal Contacte}

$$
\underline{a t}
$$

Selected Agencies

to

Determine Feasibility

of

Cooperative Efforts :

in Connection with

the

PSU/ERDA Rescarch Program

$1 *$ 
Notes

Resulting from Personal Contacts

at

Selected Agencies

1. Arizona

A. Arizona Bureau of Mines

1. No coal research underway at present.

2. A11 operating mines are within confines of Indian Reservations in the Black Mesa Field.

3. Receipt of coal samples from the Bureau not practical.

2. Arkansas

A. Arkansas Geological Commission

1. Geological research underway.

2. Primary interest is in Tignite fields.

3. Receipt of coal samples from the cominission is feasible and they are willing to assist in the PSU/ERDA research effort.

3. Colorado

A. U.S. Geological Survey

1. Has extensive coal geology research program underway.

2. Has extensive study of trace elements in coal underway.

3. Is cooperating with various states in core drilling program.

4. Is willing to cooperate with PSU in an exchange of samples and data.

5. Wi11 assist PSU/ERDA research effort by providing cores from the Montana, Wyoming areas.

4. Illinois

A. IT1 inois Geological Survey

1. Geulugical and utilization research extensivc and long standing.

2. Possesses extensive computerized data base developed from the analysis of 250,000 drill cores.

3. Survey personnel will provide assistance, advice, and information for the PSU/ERDA research effort.

B. Southern Illinois University

1. Geological and petrological research underway.

2. Has created Coal Extraction and Utilization Research Center.

3. New U.S. Bureau of Mines Station adjacent to the Uni versity.

4. Desires to sub-contract with PSU to assist in sample collection for the PSU/ERDA research effort. 
5. Indiana

A. Indiana Geological Survey

1. The Survey has a deep drilling program underway.

2. Geological research underway.

3. Cooperation with the PSU/ERDA research effort indicated.

6. Kansas

A. Kansas State Geological Survey

1. The Survey can assist the PSU/ERDA research effort by providing lists of operating coal mines and. new mine openings.

7. Kentucky

A. Kentucky Geological Survey

1. Has extensive coal genlogy research effort underway.

2. Will assist in the PSU/ERDA research effort but supplying samples may not be feasible.

8. Missouri

A. Geological Survey of Missouri

1. Has adrilling program underway and is willing to make samples available tu lie PSU/ERDA research effort.

2. Recommended drilling and sampling in Mercer and Harrison Counties.

3. Is willing to assist the PSU/ERDA research effort by collecting particular samples requested by PSU.

9. Montana

A. Montana Bureau of Mines and Geology

1. Is involved in cooperative drilling program with II.S.R.S.

2. Is establishing an Analytical Laboratory to perform coal analyses.

3. Has a coal geology research program underway.

B. Montana Department of Natural Resources and Conservation

1. Is concerned with coal development in Montana and its environmental impact.

2. The Energy Planning Division may be able to supply samples to the PSU/ERDA research effort when and if new exploratory drilling programs are undertaken.

10. New Mexico

A. New Mexico Bureau of Mines and Mineral Resources

1. The Bureau occasionally obtains cores and might be able to supply samples to the PSU/ERDA research effort.

2. The Bureau can supplyalist of active mines and mine contacts. 
11. North Dakota

A. North Dakota Geological Survey

1. The Survey is currently involved with a drilling program and typically the samples are analyzed by the U.S.G.S.

2. Cooperation with the PSU/ERDA research effort is possible.

3. Mining activity and coal production in North Dakota are increasing.

4. The Survey is cooperating with the University of North Dakota in their ERDA sponsored research.

12. Oklahoma

A. OKlahoma Geological Survey

1. The Survey does not have the personnel to assist in a sampling program but it can provide information on mines and mine contacts as a means of assisting the PSU/ERDA research effort.

2. The Survey has an active coal geology research program underway and otters short courses in coal geology.

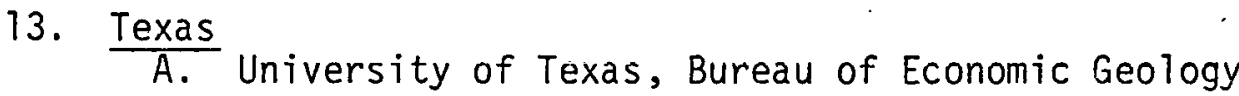

1. Has a coal geology research program underway.

2. Can supply PSU with information on mines and mine contact.

3. Can supply PSU with coal samples to assist in the PSU/ERDA research effort.

B. Texas A \&.M University

1. Is establishing a coal research program.

2. Is involved with a major underground gasification project.

3. Will have a core drilling program underway.

4. Will establish an analytical laboratory to conduct coal analyses.

5. Desires to sub-contract to PSU to assist in the PSU/ ERDA research effort:

a. by sampling under PSII guidance,

b. by providing core samples,

c. by performing analyses.

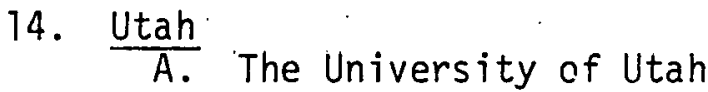

1. Is expanding into coal characterization research.

2. Has a large, active coal utilization research program underway.

3. Desires to sub-contract to PSU to assist in the sampling operations associated with the PSU/ERDA research effort. 
15. West Virginia

A. West Virginia University

1. Has a coal research program underway.

2. Desires to sub-contract to PSU to provide samples for the PSU/ERDA research effort.

16. Wyoming

A. Wyoming Geological Survey

1. Has an active coal geology research program underway.

2. Has an active drilling program underway with samples being analyzed by the U.S. Bureau of Mines and the U.S. Geological Survey.

3. Will conduct some channel sampling in the Hanna Basin and will supply PSU with splits of samples to assist the PSU/ERDA research effort. 